\title{
1
}

\section{Introduction: Emotional Entanglements of Sacrality and Secularity-Engaging the Paradox}

\author{
Markus Balkenhol, Ernst van den Hemel, \\ and Irene Stengs
}

How, in various places across the world, do religious emotions and national sentiment become entangled? In exploring this theme, this book focuses on such diverse topics as the dynamic roles of Carnaval in Brazil, the public contestation of ritual in Northern Nigeria and the culturalization of secular tolerance in the Netherlands. What binds the chapters in this volume is the focus on the ways in which sacrality and secularity mutually inform, enforce and spill over into each other. The case studies offer a bottom-up, practice-oriented approach in which the authors are

M. Balkenhol • E. van den Hemel

Meertens Institute, Amsterdam, The Netherlands

e-mail: markus.balkenhol@meertens.knaw.nl;

Ernst.van.den.hemel2@meertens.knaw.nl

I. Stengs (欧)

Meertens Institute, Amsterdam, The Netherlands

Vrije Universiteit Amsterdam, Amsterdam, The Netherlands

e-mail: Irene.stengs@meertens.knaw.nl 
wary to use categories of religion and secular as neutral descriptive terms. At this moment in time, it has become somewhat of a stale repetition to criticize the secular-religious divide. We are very much part and parcel of a world in which these boundaries overlap, are claimed, contested, reclaimed and re-contested in new and dynamic ways. If the debate on the postsecular has taught us anything, it is that the tools with which we work are implicated in these contestations. The notions 'secular', 'sacred' and 'religion' are as much part of our conceptual toolbox as objects of investigation. In order to illustrate how we are always in the middle of things, and in order to see how we should, if we are to understand the entanglements of sacrality, religion and secularity, think our way up from praxis, we opt for a start in medias res. We therefore open this introduction in Bangkok, Thailand, 26 October 2017 to be precise, when the mourning rituals for the recently deceased king are about to reach their apex.

\section{The Thai King as Secular and Sacred}

Again, thousands and thousands of people have come to the sacred heart of the 'City of Angels' (khrungthep) to get as close as possible to the place where King Bhumibol Adulyadej of Thailand (r. 1946-2016) will be cremated. One day earlier, at 5 AM, the gate had opened briefly to allow several thousand people in, most of whom had been waiting for three days and nights, enduring burning sun and heavy rains, in the hope of being among the happy few to enter. The early morning television news interviews one of them, a young woman in tears, overwhelmed by exhaustion and gratefulness: she will show her love, respect and gratitude to 'father' in the closest proximity possible for an ordinary person. This Thursday, the day of the actual cremation, people have been queuing since the early morning at various replicas of the Royal Crematorium Stadium, to offer sandalwood funeral flowers in commemoration of the king. It would take people up to eight hours to reach the spaces in front of the cremation replicas to offer their flowers. At the Royal Plaza, the square with the most important replica in terms of size and centrality, the crowd has grown to such a size that even the streets leading to the actual beginning of the queue are completely congested. What makes people want to endure such hardships? 
One possible answer lies in the specific figure and reign of the king himself. The death of King Bhumibol on 13 October 2016 left many in the kingdom in grief and confusion. With his seventy years' reign, only a few of his subjects had lived without him on the throne. In the general perception, the king, working hard and suffering difficult circumstances, had lived a life of self-sacrifice for the wellbeing of the nation and the people. In tribute, people would be very much willing to endure their one-day-only hardship.

Another possible answer lies in a specific entanglement of religion and politics. The emotional mass pilgrimage to the mourning site and the eventual cremation for one part attests to the sacred status of the Thai king. This sacredness draws on Hindu-Buddhist notions of the 'righteous ruler' whose charismatic royal merit and virtue (bun barami) are supposed to protect and sustain the nation and its people. In this perception, the monarch is regarded as a beneficial power above politics. In the course of his long reign, King Bhumibol gained currency as 'pillar of stability' in a country where politics are characterized by a seemingly endless sequence of coups d'états, new constitutions and corruption scandals.

The sacrality of the king seems obvious in this context, yet it would be wrong to suggest that people's devotion to the king is owed exclusively to the religiosity of the Thai people, to a kind of inherent magical thinking. It is not uncommon for Western media outlets to present Thai royal rituals as somewhat outlandish expressions of extreme religiosity. As orientalist perceptions of Asian religiosity tend to do, such exoticism blinds our understanding of specific intricacies of religious-political entanglements. For instance, when highlighting the religious dimension, one obscures the fact that the Thai king is not only a religious figure, but also someone of political presence in a secular state, if only as the single most important national symbol.

Within the legal framework of the Thai state, a nominally democratic regime of popular sovereignty upholding a religiously pluriform society, the king - the head of state-has no formal political authority, and his tasks are limited to specific ceremonial executive duties. The Thai statewhether governed by an elected government or by a military junta-follows a secular model. Yet, whatever the regime, the king is brought forward as the symbol of sovereignty of a democracy. Hence, devotion to the king implies devotion to the (secular) nation. This raises the issue 
how this formally secular nation relates to the equally uncontested sacredness of the king. ${ }^{1}$ In order to understand the political and religious implications of a shared mourning ritual such as that for the recently deceased Thai king, we would need to unpack carefully the ways in which religion, secularity, power and popular emotion are conjointly invested.

Such questions how secular and sacred authority is enmeshed make up the central theme of this book. How, in various places across the world, do religious emotions and national sentiments become entangled? The Thai example resonates in many ways with other spectacles of religioussecular belonging. Across the world religion and nationalism are rearticulated in new modes that often challenge existing paradigms and approaches. From the Brazilian carnaval, with its roots in religious festivities, its development into secular celebration, which in turn is embraced by national politicians as hallmark of Brazilian national identity (see Oosterbaan and Godoy in this volume), to the ways in which religious diversity in Nigeria is performed and challenged by spatial practices such as the Ashura ritual procession, performed by Shia Muslims (see Ibrahim), from public transgressions and expressions of disgust through graffiti in the streets of Berlin (see Verrips), to the magical power of colonial statues in the Dutch national imagination (see Balkenhol), the role of religion and secularity, sacrality and profanation in demarcating communities increasingly demands our attention. Over the past decades, we have witnessed a spectacular rise of often polarizing sentiments concerning religion and national identification across Europe and the globe. In Europe, feelings of home, emotional appeals to community and even the 'people' (Volk) are entwined with and fueled by the increasing presence of religion in European public spheres, long considered to have been thoroughly secularized. For instance, new nationalists and the continent's political and cultural elites frame the presence of Islam as a threat to the 'secular' character of the nation. At the same time, religious, for example, 'JudeoChristian' roots of secular nations are increasingly mobilized (Hemel 2014).

In short, contrary to the commonly held view that nationalism offers an alternative imagined community for the religious community

\footnotetext{
${ }^{1}$ The political relevance of this question is demonstrated by a ruling of the constitutional court in August 2019, that the Thai king is above the constitution.
} 
(Cavanaugh 2011), this book is inspired both by recent developments in which religion, secularity and nationalism are interconnected in new ways, as well as by recent scholarly approaches that are sensitive to the interconnections of nationalism and religion. Generally, scholars have traditionally identified nationalism as religion, nationalism or religion, and nationalism and religion (Anderson 1983; Safran 2002). Instead of focusing on the creation of meta-categories, we argue that religion and secular nationalism can both partake in processes of sacralization and desacralization. This book focuses, not on the separation of categories, but on the interconnections and the new forms of sacrality that arise as a result of new connections (Meyer and de Witte 2013). As the mourning rituals for the Thai king demonstrate, the emotions involved are connected simultaneously with the secular Thai state, with the king as its religious figurehead, and with the modes of belonging that are produced by its interconnections (see Stengs, this volume). Secular nationalism and religious dimensions are connected in many ways and we need to unpack the many folds carefully and according to the context in which they arise. A focus on emotions, we propose, allows us to bring together practices, both religious and secular, that are often studied in isolation. We propose to approach the way in which emotions are implicated, performed and become legible by using a concept we call 'the secular sacred'.

\section{The Secular Sacred: A Praxeological Approach}

The Thai king, 'Upholder of the Buddhist Religion, and Defender of the Faith' and head of a religiously diverse secular state, but also the sanctification of tolerance as a 'Judeo-Christian value', and the human right of religious freedom, used as a global value to define and defend religious practices (see Salemink in this volume) are all examples of what we call a 'secular sacred': a person, object, image, representation or place in which secular and sacred ideas, feelings, emotions, motivations, experiences, perceptions, intertwine, conflate and conflict. We take the secular sacred to denote the intertwining processes of secularization and sacralization. This entanglement works both ways: sacred objects can take on new functions in secular imaginations, gazes and practices, thereby potentially 
losing or at least transforming their sacredness in the process. Inversely, secular practices and values can take on well-nigh sacred dimensions as they become the subject of worship or interdiction. All of these entanglements are objects of study in what we call the secular sacred.

We deliberately use the articulation of 'secular' and 'sacred' to distinguish the 'secular' from the 'profane'. Whereas the profane, in the words of Roger Caillois (1959), the sphere of common usage, is opposed to the sacred (an ambiguous domain of fear and hope and characterized by danger), the secular is not. Following scholars like Talal Asad, we argue that the secular contains or even emerges through processes of sacralization. In Asad's words, the secular:

(...) is neither continuous with the religious that supposedly preceded it (that is, it is not the latest phase of a sacred origin) nor a simple break from it (that is, it is not the opposite, an essence that excludes the sacred). (2003: 25)

Instead of the opposite of religion, Asad understands the secular to be an ordering principle that brings together certain 'behaviors, knowledges, and sensibilities in modern life' (ibid: 24). Saba Mahmood goes a step further by pointing out that the notion of 'the secular' is far from a neutral separation of religion and state, but should be seen as an extension of an ideological view, secularism, in which a normative bias toward Christianity is palpable:

As much of recent scholarship suggests, contrary to the ideological selfunderstanding of secularism (as the doctrinal separation of religion and state), secularism has historically entailed the regulation and reformation of religious beliefs, doctrines, and practices to yield a particular normative conception of religion (that is largely Protestant Christian in its contours). (2009: 87)

In Mahmood's understanding, to portray secularism as opposed to religion is itself an operation of secularist ideology, in which the secular conceals its quintessentially Protestant foundations. These considerations are of importance to this book not because we want to repeat a critique 
of secularity. We want to take our cue from the insight that such critical investigations of secularity mean we have to start in medias res. This book understands these critiques of secularity as an impetus to work bottom up, all the time taking our own conceptual background and trajectories into consideration.

Transcending the idea that 'the secular' and 'the sacred' are separate categories, we seek to find new and better ways to understand the current emotionally charged articulations of nationalism and religion that have come to define the beginning of the twenty-first century in many places across the globe. We propose to use the notion of the 'secular sacred' in order to analyze this worldwide phenomenon. The key innovation of this book is that it investigates this conjuncture by bringing together three focal points: emotions, nationalism and religion. We argue that this combination provides an important update to an understanding of the politics of binding, belonging and exclusion across the globe. The concept of the secular sacred allows us to focus on the processes of cultural production through which notions of the secular and the sacred emerge in specific ethnographic settings. Not seeking to define the secular or the religious, the book focuses on the boundary work through which both categories are being defined, contested and re-made in social and political practice.

The 'secular sacred', then, in this book is crafted to approach new modalities of sacrality as well as the impact of secular paradigms on more classically religious registers of sacrality. The 'secular sacred' indicates a starting point in the middle of this entanglement in order to understand how public spaces, images and bodies are constituted and contested in new ways.

Far from being an emphasis on the rational choices individuals might make, we focus on how the secular sacred unconsciously guides emotions and delineations of belonging. For instance, echoing Sara Ahmed's work on emotions, we might not know how we feel nor why we feel the way we do. The person standing before a painting by Mark Rothko who feels the tears well up might not be conscious of the tradition of sacred tears and art, nor might it be a conscious continuation of a tradition, yet as Roodenburg outlines in his description of this phenomenon, the words used to describe these experiences, the way in which Rothko describes his 
artworks all directly draw from or resonate with explicit registers of sacrality.

These shifting, coalescing, overlapping and contradicting qualities associated with secularism and religion call for a praxeological approach, paying particular attention to the involvement of the body, the emotions and the senses or, more specifically, to 'embodied practices', 'sensational forms' and sense perception (aisthesis) (Meyer 2006; Scheer 2012; Verrips 2005). Such an approach sheds light not only on how the secular and the sacred are mediated, but also on how they deeply take root in people becoming all the more persuasive. The secular sacred emphatically includes the study of objects, materials and images that would be excluded in a 'mentalistic' (Meyer 2012: 8) framework. The secular sacred is not inward and personal, but takes place precisely at the intersection of the public and the private, evoking and mediating emotions, mobilizing old and creating new publics. Taking the established notions of habitus, the body, senses, and emotions as a point of departure (Bourdieu 1977; Connerton 1989), then, may provide us with a more detailed understanding of how practices may both reproduce and (temporarily) subvert structures of power. Thus, our notion of the secular sacred implies a critical engagement with seemingly self-evident distinctions between religion and the secular inherent in Western modernity. In other words, the emergence of categories like 'religion' and 'the secular' have to be understood in the context of European colonial expansion, and the confrontation with difference it entailed (Veer 1994).

\section{Sections of this Book}

This book is structured around several 'secular sacreds' that unfold in various contexts worldwide. In particular, we present the following nodal points: culture, tolerance, public space, images and the body. Guiding principle in these sections is that the chapters take a bottom-up perspective by presenting ethnographic studies in which the nation, secular and religious dimensions entangle. Unpacking these entanglements provides us with an opportunity to revisit familiar approaches and hence formulate an updated understanding of our emotionally volatile times. 


\section{Culture}

Culture has, in recent decades, become a sacrosanct concept in many places around the world. Whereas in mainstream secularization theory the spheres of the religious and the secular drift apart, we witness, in Europe and elsewhere, both academic and politically influential approaches that emphasize interconnections, fusions and more complex relations to cultural identity. Take for instance Samuel Huntington's famous idea of a clash of civilizations, in which the fault lines of the next major conflicts were announced to be cultural (Huntington 1993). In his framework, cultural identity is defined as the most broad, far-reaching, basic identification humans are capable of. For Huntington, secularity is part and parcel of a Western, cultural framework in which religion plays a significant role. Note also how religion and secularity are part of this cultural clash:

We are facing a need and a movement far transcending the level of issues and policies and the governments that pursue them. This is no less than a clash of civilizations - the perhaps irrational but surely historic reaction of an ancient rival [Islamic civilization] against our Judeo-Christian heritage, our secular present, and the worldwide expansion of both. (Bernard Lewis, as quoted in Huntington 1993: 32)

For Huntington, secularity is part and parcel of a Western, cultural framework in which religious heritage plays a significant role. In this sense, cultural identity is frequently opposed to and triggered by critical reflections on globalization. In the twenty-first century, religion and secularity are taken up in processes of culturalization and polarization in new and often profoundly disruptive ways. This is further complicated by the fact that culture is formulated in increasingly nativist terms (Duyvendak 2011; Balkenhol et al. 2016). As Etienne Balibar argues, cultural identity can play the role nature once played, raising the question in what ways culture can function in structurally similar ways to race. Frequently what is at stake in invocations of culture is what Appadurai has called a 'community of sentiment' (Appadurai 1990: 93): 'a group that begins to imagine and feel things together'. This can take the shape 
of rather vague or even deliberately empty signifiers that invite people to attach their feelings of discomfort. The chapters in this section deploy ethnographic analysis to map how invocations of cultural communities of sentiments take place.

In his contribution, Ernst van den Hemel looks at the implications of current populist discourse on 'religion', which sets up new conflations of and juxtapositions between the secular and the religious. His analysis of a local debate by a Dutch orthodox Protestant political party shows that populist discursive practice can productively be characterized as a profoundly influential postsecular imagination. Irene Götz presents a case study on the repetitive debates on 'dual citizenship' in Germany, that has to be contextualized by a historic sketch on the 'anthropologization' of the 'national', which developed into a powerful emotional movement during the nineteenth century and started to attract the masses via cultural images and bodily practices.

\section{Public Space}

The public sphere has long been a constitutive element of 'the secular'. Presumed to be neutral, and its neutrality safeguarded by a secular state, the public sphere is, both in common parlance as well as in theory, an important site where citizens of the secular state can meet on equal footing regardless of religious outlook. Religion, concomitantly, is relegated to the private sphere (e.g. the conjugal home) where it can be practiced without interference. Such a clear distinction has become, as we have argued above, untenable considering the continued presence and newly emerging forms of public religion (Vries and Sullivan 2006), the increasingly apparent entanglements of the public sphere with religion in general and Protestantism in particular (Asad 2003; Mahmood 2009), as well as nascent questions concerning location of religion in connection to new media and globalizing currents (Knott 2005; Meyer and Moors 2006). These developments have led scholars to be wary of clear-cut distinctions between private and public spheres, and the presence or absence of religion. The spatial turn, marking a move away from place as neutral metric and toward space as constitutive, dynamic and complex, has inspired scholars of religion to ask not just what takes place in public 
places but also how space constitutes publics and vice versa how public performances constitutes public space. In a 2013 volume, for instance, Knott et al. highlight how media portrayals of religion and new media activities re-shape the role of religious and secular beliefs and values in public life. Moving beyond these critical reflections, we focus on material and spatial contestations in particular, taking place in public space. This focus on public space allows us to unpack the way in which divisions between public and private registers are far from stable but hinge upon perpetual performances and forms of public circulation. Moreover, notions of who belongs to the public sphere and the complex role of religious items, rituals and people therein, are themselves to an important degree, constituted by performances taking place in public space. From Hindu-nationalist public proclamations that public space should be dominated by a homogeneous shared culture, to the performance of public mourning as we have seen in Thailand, public space is the site of clashes and contestations in which emotions related to nationalism, religion and secularity run high. Ethnographic description and analysis of contestations in public space are ways of entry into understanding the complex forces that make up who will be seen, heard, felt and smelled and will take up a certain place in a community.

Stefan Binder, in his contribution, highlights how organized atheism presents a particular challenge to the way in which religious nationalism increasingly aligns itself with Hinduism in India. Murtala Ibrahim presents an analysis of a variety of 'pious spectacles' in Northern Nigeria in which particularly the rituals of Shia Muslims highlight questions of visibility, contestations and presence of religious pluriformity. In their chapter, Martijn Oosterbaan and Adriano Godoy present an analysis of Brazilian carnaval, where the festive body is framed by overlapping layers of religion, popular culture and national identity.

\section{Tolerance}

Originally a concept that arose in Western Europe to manage conflicts between Protestants, tolerance developed for many into a hallmark of Western modernity. Continuously, the notion served to regulate differences, but also to demarcate communities along moral lines. Tolerance 
has proven a tricky and at times paradoxical notion, however. Karl Popper has described the 'paradox of tolerance' as follows: 'Unlimited tolerance must lead to the disappearance of tolerance. ... We should therefore claim, in the name of tolerance, the right not to tolerate the intolerant' (Popper 1945: 226). But how are the borders between tolerance and intolerance defined and policed?

In recent decades, the nature and boundaries of tolerance have become a hotbed of debate, division and conflict. According to Wendy Brown, there has been something of a global renaissance in discourse on tolerance. Tolerance is now enumerated and promoted at the United Nations, in the context of human rights campaigns, as a tool of managing diverse societies, as a key to pacifying racially divided neighborhoods, or in the context of LGBTQ+ rights. Tolerance has become transpolitical as it is being mobilized by progressives, liberals, conservatives, fundamentalist Christians and atheists alike:

tolerance knows no political party: it is what liberals and leftists reproach a religious, xenophobic, and homophobic right for lacking, but also what evangelical Christians claim that secular liberals refuse them and what conservative foreign policy ideologues claim America cherishes and 'radical Islamicists' abhor. (Brown 2009: 3)

What originated as a theological and philosophical debate about freedom and the state has in recent years turned into a sacrosanct essence through which various actors define themselves.

The three articles in this section each take up this changing character of the notion of tolerance. Oscar Salemink describes how tolerance is central to human rights discourse, and the implications of the global use of tolerance. In particular, he explores how religious toleration in Vietnam is used by a variety of actors to claim (inter)national recognition. The case of spirit possessions in Vietnam provides a particularly poignant example of the disciplinary implications of global tolerance. Josip Kešić and Jan Willem Duyvendak argue that tolerance is mobilized from a quasihistorical perspective in which it incorrectly appears as a continuous history since the time of Spinoza. This selective history of the concept implies the 'forgetting' of many other periods in which the Dutch were 
conservative and intolerant. Alex van Stipriaan asks how this famed Dutch tolerance functions within a history of extreme asymmetrical relations between white and black in Dutch history from slavery up till today. Is tolerance a white privilege? If so, is there also black tolerance? And what does tolerance mean in the (coming?) age of reparations and reconciliation?

\section{Images}

Images are often found at the heart of controversies around where to draw the line between the secular and the religious: at what point does an image lose or gain its sacredness, where does freedom of expression end, and blasphemy begin (Kruse et al. 2018)? Cartoons of the Prophet Mohammed or the protests by Pussy Riot and Femen have become scandalous precisely because they test and redefine the limits of tolerance, free speech and transgression. In short, the boundaries of the secular and the sacred are not given, but emerge through an engagement with images.

People not only embrace or reject certain images, but they show strong bodily and affective responses. Cases of blasphemy, for instance, can cause literal disgust or nausea, but images, both religious and profane, can also be held dear and caressed. All of these processes deeply involve the body, the senses and emotions. In the words of Hans Belting the significance of images 'becomes accessible only when we take into account other, non-iconic determinants such as, in a most general sense, medium and body' (Belting 2005: 302). The body may be both performing and perceiving, but Belting regards bodies as central to an understanding of the significance of images. This resonates with the idea of religion as an outward form that exerts influence beyond religious contexts as such, but intersects with politics and society at large.

The contributions in this section engage with black Atlantic and Dutch settings. Markus Balkenhol looks at the international controversies about colonial statues through the lens of the Dutch case of Jan Pieterszoon Coen, widely seen as a maritime hero of the Dutch Golden Age, but also infamous for his brutal reign in the Dutch East Indian colonies. Balkenhol looks at how the magical power of statues is harnessed, disavowed and 
contested. At stake here is the modern subject whose supposed secularism is constantly undermined by magic. Herman Roodenburg analyzes the way in which the abstract art of Mark Rothko is the subject of processes of secular sacralization. Analyzing the tears viewers shed in front of his monochrome artworks, Roodenburg outlines the way in which registers of the sacred and profound bodily reactions to sacred images such as tears cross over into the domain of modern art.

\section{Bodies}

In societies where issues of secular and sacred values are at stake, the body invariably becomes the object of fierce debate. Debates on the status of the body are a hallmark of secularizing society where secular autonomy has frequently clashed with more explicitly confessional oriented conceptualizations of the body. However, more important than re-hashing the struggle between liberal autonomy and confessional dependence, this book aims to highlight what binds approaches to the body. The sovereignty of the body as the ultimate locus of self-understanding, indisputable site of existential experience and embodied knowledge has attained a sacred value in many societies (Csordas 1994). This leads to all sorts of new clashes. For instance, the universal rights of personal freedom and integrity of the body often clash with the sovereign secular power of the nation-state, which aims to discipline human bodies by exercising rules and regulations, politics that often include violence. The body is thus also a visual marker of autochthony and belonging (Geschiere 2009). The immanent transcendental potential in bodies is often most palpable during emotional events that celebrate the nation-state or other communities, such as commemorative ceremonies, sport celebrations, election victories, entailing processes of sacralization in which bodies play a pivotal role (see Emile Durkheim's (1915) and Victor Turner's (2018) respective notions of effervescence and communitas). In our view, this shows that such communities are not simply 'imagined' (Anderson 1983), but that they take shape through emotional and visceral engagements (Meyer 2009). 
The essays in this section reflect these tensions: through his discussion of disgust as a deeply physical sentiment that is in close proximity to the sacred, Jojada Verrips analyzes how linguistic violence is part and parcel of both the religious as well as the secular sacred. Verrips focuses on vulgar graffiti on glass containers in Berlin, where a scatological debate on immigrants is waged. Verrips takes up this mundane occurrence in order to analyze how disgust informs both contemporary polarization as well as the reactions to contemporary political linguistic violence. Irene Stengs presents an ethnographic analysis of the vast movements and choreographic ritual arrangements of Thai mourning King Bhumibol in blackand-white colored bodies. She demonstrates how the massive emotional ritual outpour for one part was grounded in a fierce and coercive royalistnationalism, and for another part has been organized by and disseminated along the administrative state structure. The Thai secular administration, in other words, is pivotal in (re)producing the sacrality of the monarchy.

The essays thus contribute to both a practical understanding of these individual contexts, as well as to an overarching conceptual debate. Taking our cue from Birgit Meyer, these contributions focus on 'the network of relations that make the sacred a social reality (...) what bodies and things do, on the practices that put them to work, on the epistemological and aesthetic paradigms that organize the bodily experience of things (...)' (Meyer et al. 2010: 209). Paying attention to concrete embodied practices, as well as the lives of images and the performance in public space, enables us to understand in better detail how specific relations of power inform and transform people's lives.

\section{References}

Anderson, B. (1983). Imagined Communities: Reflections on the Origin and Spread of Nationalism. London, New York: Verso.

Appadurai, A. (1990). Topographies of the Self: Praise and Emotion in Hindu India. In C. Lutz \& L. Abu-Lughod (Eds.), Language and the Politics of Emotion (pp. 92-112). Cambridge: Cambridge University Press. 
Asad, T. (2003). Formations of the Secular: Christianity, Islam, Modernity. Stanford, CA: Stanford University Press.

Balkenhol, M., Mepschen, P., \& Duyvendak, J. W. (2016). The Nativist Triangle. Race, Sexuality and Religion in the Netherlands. In J. W. Duyvendak, P. Geschiere, \& E. Tonkens (Eds.), The Culturalization of Citizenship. Belonging and Polarization in a Globalizing World (pp. 97-112). New York [etc]: Palgrave Macmillan.

Belting, H. (2005). Image, Medium, Body: A New Approach to Iconology. Critical Inquiry, 31(2), 302-319.

Bourdieu, P. (1977). Outline of a Theory of Practice. Cambridge: Cambridge University Press.

Brown, W. (2009). Regulating Aversion: Tolerance in the Age of Identity and Empire. Princeton, NJ: Princeton University Press.

Caillois, R. (1959). Man and the Sacred. Champaign, IL: University of Illinois Press.

Cavanaugh, W. T. (2011). Migrations of the Holy: God, State, and the Political Meaning of the Church. Grand Rapids, MI: Eerdmans.

Connerton, P. (1989). How Societies Remember. Cambridge: Cambridge University Press.

Csordas, T. J. (1994). Embodiment and Experience: The Existential Ground of Culture and Self(Vol. 2). Cambridge: Cambridge University Press.

Durkheim, É. (1915). The Elementary Forms of Religious Life. London: George Allen and Unwin.

Duyvendak, J. W. (2011). The Politics of Home: Belonging and Nostalgia in Western Europe and the United States. London: Palgrave Macmillan.

Geschiere, P. (2009). The Perils of Belonging: Autochthony, Citizenship, and Exclusion in Africa and Europe. London and Chicago, IL: University of Chicago Press.

Hemel, van den E. (2014). (Pro)claiming Tradition: The 'Judeo-Christian' Roots of Dutch Society and the Rise of Conservative Nationalism. In R. Braidotti, T. de Graauw, B. Blaagaard, \& E. Midden (Eds.), Transformations of Religion and the Publics Sphere. Postsecular Publics (pp. 14-33). New York [etc.]: Palgrave Macmillan.

Huntington, S. (1993). The Clash of Civilizations. Foreign Affairs, 72(3), 22-49. Knott, K. (2005). The Location of Religion: A Spatial Analysis. Sheffield: Equinox Publishing. 
Knott, K., Poole, E., \& Taira, T. (Eds.). (2013). Media Portrayals of Religion and the Secular Sacred. Surrey and Burlington: Ashgate.

Kruse, C., Meyer, B., \& Korte, A. (Eds.). (2018). Taking Offense: Religion, Art, and Visual Culture in Plural Configurations. Leiden: Brill.

Mahmood, S. (2009). Religious Reason and Secular Affect: An Incommensurable Divide? In T. Asad, W. Brown, J. Butler, \& S. Mahmood (Eds.), Is Critique Secular? Blasphemy, Injury, and Free Speech (pp. 58-94). Berkeley, CA: The Townsend Center for the Humanities.

Meyer, B. (2006). Religious Sensations: Why Media, Aesthetics and Power Matter in the Study of Contemporary Religion. Amsterdam: Vrije Universiteit.

Meyer, B. (2009). Aesthetic Formations: Media, Religion, and the Senses. New York [etc.]: Palgrave Macmillan.

Meyer, B. (2012). Mediation and the Genesis of Presence: Towards a Material Approach to Religion. Utrecht: Utrecht University.

Meyer, B., \& de Witte, M. (2013). Heritage and the Sacred: Introduction. Material Religion: The Journal of Objects, Art and Belief, 9(3), 274-280.

Meyer, B., \& Moors, A. (2006). Religion, Media, and the Public Sphere. Bloomington, IN: Indiana University Press.

Meyer, B., Morgan, D., Paine, C., \& Brent Plate, S. (2010). The Origin and Mission of Material Religion. Religion, 40(3), 207-211.

Popper, K. (1945). The Open Society and Its Enemies (The Spell of Plato) (Vol. 1). London and New York: Routledge.

Safran, W. (Ed.). (2002). The Secular and the Sacred: Nation, Religion and Politics. London: Routledge.

Scheer, M. (2012). Are Emotions a Kind of Practice (and Is That What Makes Them Have a History)? A Bourdieuian Approach to Understanding Emotion. History and Theory, 51(2), 193-220.

Turner, V. (2018). Dramas, Fields, and Metaphors: Symbolic Action in Human Society. Cornell, NY: Cornell University Press.

Veer, van der P. (1994). Religious Nationalism: Hindus and Muslims in India. Berkeley, CA: University of California Press.

Verrips, J. (2005). Sensing - Aisthesis \& An-Aesthesia. Ethnologia Europaea: Revue Internationale d'ethnologie Européenne, 35(1/2), 29-36.

Vries, de H., \& Sullivan, L. E. (2006). Political Theologies: Public Religions in a Post-Secular World. New York: Fordham University Press. 
Open Access This chapter is licensed under the terms of the Creative Commons Attribution 4.0 International License (http://creativecommons.org/licenses/ by/4.0/), which permits use, sharing, adaptation, distribution and reproduction in any medium or format, as long as you give appropriate credit to the original author(s) and the source, provide a link to the Creative Commons licence and indicate if changes were made.

The images or other third party material in this chapter are included in the chapter's Creative Commons licence, unless indicated otherwise in a credit line to the material. If material is not included in the chapter's Creative Commons licence and your intended use is not permitted by statutory regulation or exceeds the permitted use, you will need to obtain permission directly from the copyright holder.

(c) (1) 